\title{
El Niño adversely affected childhood stature and lean mass in northern Peru
}

\author{
Heather E Danysh ${ }^{1,2}$, Robert H Gilman 1,2, Jonathan C Wells ${ }^{3}$, William K Pan ${ }^{4}$, Benjamin Zaitchik ${ }^{5}$, \\ Guillermo Gonzálvez ${ }^{6}$ María Alvarez ${ }^{6}$ and William Checkley ${ }^{1,7^{*}}$
}

\begin{abstract}
Background: El Niño is responsible for natural disasters and infectious disease outbreaks worldwide. During the 1997-1998 El Niño, northern Peru endured extreme rainfall and flooding. Since short stature may occur as a result of undernutrition or repeated infections during childhood, both of which are highly prevalent during natural disasters, we sought to determine if the 1997-1998 El Niño had an adverse effect on stature and body composition a decade later. In 2008-2009, we measured height, weight, and bioimpedance in a random sample of 2,095 children born between 1991 and 2001 in Tumbes, Peru.

Results: Height-for-age increased by 0.09 SD/year of birth between 1991 and $1997(P<0.001)$, indicating overall improvements in health over time in the study area; however, this rate fell to 0.04 SD/year of birth during and shortly after El Niño, less than half the rate prior to El Niño $(P=0.046)$. Height shortfalls were even greater in children residing in households most likely to be flooded after El Niño. Any improvement over time was completely blunted and became negative in children living in households with flood likelihoods of $\geq 7 \%(P=0.001)$. In the subset of 912 children with bioimpedance measurements, those born after the onset of El Niño had less lean mass $(P<0.001)$, whereas fat mass was unaffected $(P=0.48)$.

Conclusions: Children born during and after 1997-1998 El Niño were on average shorter and had less lean mass for their age and sex than expected had El Niño not occurred. The effects of El Niño on health are long lasting and, given its cyclical nature, may continue to negatively impact future generations.
\end{abstract}

Keywords: El Niño, Flood, Child growth, Height, Lean mass

\section{Introduction}

The El Niño phenomenon is an anomalous warming of sea surface temperatures (SST) in the equatorial Pacific that causes extreme weather variability every 2 to 7 years [1], leading to disaster and disease worldwide. During $E l$ Niño episodes, natural disasters such as severe drought and floods are estimated to affect 35 per 1,000 people, more than four times the rate affected by natural disasters during non-El Niño years [2]. El Niño episodes have been linked to increased incidences of malaria [3-6], dengue [7-10], cholera [11-10], and diarrhea [15,16], all

\footnotetext{
* Correspondence: wcheckl1@jhmi.edu

'Program in Global Disease Epidemiology and Control, Department of International Health, Bloomberg School of Public Health, Johns Hopkins University, Baltimore 21218, USA

7Division of Pulmonary and Critical Care, Johns Hopkins University, 1830 Monument St, Fifth Floor, Baltimore, MD 21205, USA

Full list of author information is available at the end of the article
}

of which are highly prevalent in the developing world. Even small increases in any of these diseases translate into hundreds of thousands of deaths and millions affected.

While many studies have evaluated the short-term effects of El Niño episodes such as an increase in the burden of infectious diseases, the long-term consequences on human health have not been studied. Due to the recurrent and global nature of $E l N i \tilde{n} o$, it is important that we gain a better understanding of possible long-term adverse effects on the health of affected human populations. One such measure of poor health is failure to grow adequately in height, also known as stunting. Small stature for a given age and sex is a surrogate measure of chronic malnutrition [17]. Stunting occurs in early childhood as a result of undernutrition, a high burden of infectious diseases, or both [18]. In developing countries, height deficits incurred early in life generally persist through childhood and even 
adulthood $[19,20]$ and have been linked to other developmental problems including delayed motor [21] and locomotion skills [22], cognitive impairment [23], delayed school enrollment [24] and poor school performance [25], lower adult productivity [26], and higher risk pregnancies and deliveries.

El Niño impacts communities throughout the world; however, the northern coastline of Peru suffers the greatest effects of $E l$ Niño episodes through heavy rainfall and severe flooding. During the 1997-1998 El Niño episode, the most severe on record, the Peruvian government received an early forecast of its potential severity 6 months prior to the onset of heavy rains. The government developed a prevention strategy that centered on the preservation of infrastructure and construction and repair of irrigation and drainage systems [27]. Despite these efforts, overflowing riverbanks cut off access to bridges and roads and isolated many rural villages in northern Peru, some for months at a time. Food, clean water, and healthcare were largely inaccessible in these villages, and increased cases of malaria and diarrhea were reported throughout the region [5,28]. Severe damage to crops and livestock limited food reserves and severed an important source of income for most rural residents. Due to severe food shortages and increased incidence of infectious diseases during El Niño, we hypothesized that children born in northern Peru during and after the 1997-1998 El Niño may be shorter for their age and sex than children born in other years. In 2008-2009, we visited a random sample of children born between 1991 and 2001 in a cluster of rural villages in Tumbes, Peru, and measured their height, weight, and bioelectrical impedance. As secondary objectives, we also examined 1) whether children born after the onset of El Niño had differences in later body composition (lean mass (LM) and fat mass (FM)) and 2) whether birth and death rates in Tumbes changed significantly in 1997-1998, the period of El Niño, using data collected by the Peruvian National Institute of Statistics and Information between 1994 and 2002.

\section{Methods}

\section{Study setting}

The Department of Tumbes is located in the northern coast of Peru ( $9^{\circ} \mathrm{S}$ of the equator). Our study area consists of a group of communities with about 20,000 people over $80 \mathrm{~km}^{2}$ where the traditional agricultural landscape has become intermixed with rapid urbanization. Average ambient temperatures range $23^{\circ} \mathrm{C}-31^{\circ} \mathrm{C}$ during the rainy season (December to May) and $21^{\circ} \mathrm{C}-28^{\circ} \mathrm{C}$ during the dry season (June to November).

\section{Study design}

In November 2008 through December 2009, we conducted a cross-sectional study of children in 59 rural villages who were born between 1991 and 2001. We calculated that we would require 698 children per age strata (prior, during, and after the 1997-1998 El Niño) to detect a 0.15 SD difference (SD) in height-for-age (HAZ) due to the 1997-1998 El Niño episode with a variance of 1 SD for HAZ, 95\% confidence, and $80 \%$ power. We excluded children who did not live in the study area since 1 year of age and limited enrollment to only one child per household. Using a recent local census conducted in early 2008, we randomly selected 2,456 children, based on year of birth, from 59 villages in Tumbes and who were born between January 1, 1991 and December 31, 2001. The majority of children who were not enrolled in the study had either moved between the census date and date of enrollment (54\%) or could not be located for other reasons (22\%). An additional 19\% did not meet study inclusion criteria and $6 \%$ refused to participate. A total of 2,095 (84\%) children met the eligibility criteria, agreed to participate, and were enrolled in the study. Following informed consent, the child's parent completed a survey that included information on household characteristics (e.g., construction materials, fuel used for cooking, source of drinking water, type of sanitation facility, ratio of bedrooms to household members), household assets (e.g., appliances and vehicles), parental occupation, parental education, and migration history of the child. We measured the child's height and weight as previously described [29]. In a subset of children, we measured bioelectrical impedance to estimate both LM) and FM. To account for seasonality, all nutritional measurements were conducted during the November and December months across 2 years (2008 and 2009). The Institutional Review Boards of A.B. PRISMA (Lima, Peru) and Johns Hopkins University (Baltimore, USA) approved this study. Participants aged $\geq 18$ years provided written informed consent. Children aged $<18$ years provided assent, and parents provided written informed consent on their behalf.

\section{Nutritional indicators}

We calculated HAZ using the 2007 World Health Organization Reference for children 5 to 19 years of age [29]. We measured body composition in a subset of children using bioelectrical impedance, a simple field prediction method widely used in children and specifically calibrated for application in our sample. We measured total body water in children using a foot-to-foot impedance scale, the Tanita BF300 (Tanita Corporation, Tokyo, Japan). Bioelectrical impedance analysis requires calibration in each study population against a gold standard measurement of total body water obtained by isotope dilution [30,31], in which 70 children from our sample participated. We calculated lean mass (in kilograms) using age (in years), height (in centimeters), and impedance (in ohms) as previously 
described [32] with the following equation: $\ln$ (lean mass $)=0.206+\left(0.829 \times \ln \frac{\text { height }^{2}}{\text { impedance }}\right)+(0.022 \times$ age $)$. We estimated fat mass in kilograms as the difference between total weight and lean mass.

\section{Calculation of flooding index}

Disruptions and damages reported in Tumbes during the 1997-1998 El Niño were largely due to high precipitation and resulting flooding. Therefore, we hypothesized that flooding may be an independent risk factor for a lower achieved stature, and the degree of flooding may be linked to greater shortfalls in height during El Niño episodes. There were four El Niño episodes between 1991 and 2001 including weaker events in 1991-1992, 19921993, and 1994-1995. The strongest El Niño occurred in 1997-1998 during which annual rainfall in Tumbes was 2,500mm, 12 times greater of what is normally expected in any given year. We calculated a flood likelihood score which represents the likelihood that a child lives in a household that was prone to flooding between the period of 1991 and 2001. The flood likelihood score was computed using longitude and latitude coordinates for each child's household and percent soil saturation estimates at that location for the period of 1991-2001, which were generated from simulations with the Noah Land Surface Model $[33,34]$ and meteorological data from the National Aeronautics and Space Administration Modern-Era Reanalysis for Research and Applications [35]. Specifically, flood likelihood scores were calculated for each child's household in two steps. First, we used a generalized linear mixed model with an identity link to estimate smoothed soil moisture estimates over time that accounted for repeated measures for each child's household. We estimated several time and space specifications to identify the best fit for this model, with model fit maximized with our final specification (village, month, year, and month by year interaction fixed effects; an autoregressive repeated measures covariance structure; and random effects for household location). We then calculated studentized residuals and defined flooding as a residual value greater than 2 , which represents areas with a soil saturation greater than 97.5\% of other areas. The second step involved taking the number of months since birth for each child (until 2001) that their household was defined as flooded and estimated the predicted probability that a child lived in a location prone to flooding using another generalized linear mixed model with a logit link. The calculated predicted probabilities were used as the flood likelihood score for our analyses.

\section{Crude birth and death rates}

We used local public registries to obtain data on all births and deaths that occurred in five out of seven districts in the Department of Tumbes during 1994 to 2002. Crude rates were calculated based on projected population totals in those five districts for the corresponding years (Peruvian National Institute of Statistics and Information).

\section{Biostatistical methods}

We used linear mixed models to assess the association between being born before or after the onset of the 1997-1998 El Niño and height in later childhood. Specifically, the model included two indicators of birth date to investigate the effect of being born before compared to being born after the onset of the El Niño episode on the distribution of HAZ. The first birth date indicator was the number of years between the each child's birth date and January 1991, modeled as a continuous variable. The second birth date indicator, also modeled as a continuous variable, was assigned the following values according to the date of onset of El Niño in July 1997: 1) the number of years between the child's birth date and the onset of El Niño for the each child born after the onset of El Niño and 2) 0 for children born before. Our choice of model was supported by exploratory analyses, in which we found a linear change in the slope of HAZ with birth date after the onset of El Niño. All regression models were adjusted for sex, socioeconomic status (SES) index, and likelihood of living in a flood-prone household, and accounted for clustering using a random intercept by village. All confounding variables were selected a priori. Principal components analysis was used to generate the SES index using a combination of variables for household characteristics, household assets, and maternal educational attainment (all variables included in the SES index are listed in Additional file 1: Table S1) [36,37]. We also tested for an interaction between flood likelihood and $E l$ Niño (the second birth date indicator variable). To investigate the differences in body composition, we used a bivariate linear mixed model to investigate the effect of the 1997-1998 El Niño episode on the joint distribution of lean mass and fat mass. We included the two indicators for birth date and adjusted for the same covariates as described above. We present a detailed description of our analysis in Additional file 1.

Annual birth and death totals from local public registries were used to generate crude birth and death rates. Poisson regression was used to examine the change in crude infant and child mortality rates and birth rates per year between 1994 and 2002. El Niño was represented in the model similarly to the previous models with two time-predictor variables, one representing time before $E l$ Niño and the second representing time after the onset of El Niño.

Statistical analyses were conducted in SAS 9.2 (SAS Institute, Cary, North Carolina, USA) and STATA version 11 (STATA Corp., College Station, Texas, USA). 


\section{Results}

Baseline characteristics

The final sample of 2,095 children aged 7 to 18 years consisted of approximately equal proportions of children born in each year between 1991 and 2001 (Table 1), with the exception of those born in 1991, the oldest children in the sample, who were more difficult to locate. Slightly more than half the study participants were male. The largest deficits in height and the highest proportions of stunting were in those with the earliest birth dates. Children born in all years had a similar average SES index score, and each birth cohort had comparable distributions of living in a household prone to flooding between 1991 and 2001. Migration was uncommon in our cohort. Twenty-five children (1\%) were born outside of Tumbes and all were 1 year of age or younger when they moved to Tumbes. Of the remaining 99\% born in Tumbes, only 79 children $(4 \%)$ were born in a village different from the one in which they were living at the time of enrollment in our study.

\section{El Niño and extreme weather variability}

Throughout 1991-2001, periods of high sea surface temperature were associated with periods of higher precipitation and higher minimum ambient temperature in Tumbes. The 1997-1998 El Niño episode was marked by a striking increase in sea surface temperature throughout 1997 and continuing to mid-1998 (Figure 1). During this period of high sea surface temperatures, precipitation increased dramatically more than any other time throughout 1991-2001. Furthermore, periods of low sea surface temperatures were associated with periods of lower precipitation. While sea surface temperatures were high during the winter months in 1997, minimum ambient temperature did not follow the usual winter periodic trough and remained at high levels comparable to summer months.
Precipitation, runoff, gauged discharge, and percent soil water content, all used as indicators of flood potential, were significantly higher in 1998 in comparison to all other years between 1995 and 2004 in Tumbes (Figure 2A). As soil moisture was maximized in Tumbes in 1998, rice and banana production, the chief crops of agriculture, simultaneously plummeted (Figure 2B), which is consistent with the reports of food shortages and economic distress in Tumbes during the disaster. To further understand the magnitude of flooding during this time, soil saturation estimates for the months of January through April in 1998 were compared to those in these same months between 1995 and 2004 (excluding 1998) which shows that Tumbes experienced significantly higher levels of saturation in 1998, with some areas experiencing root zone soil water saturation levels up to 2.5 times greater than in other years (Figure 3 ).

\section{El Niño and height deficits}

Children born in January 1991 were on average 1.4 standard deviations below the WHO reference for height, reflecting the poor nutritional status of children in Tumbes during this period. From this point through midJuly 1997, HAZ increased linearly with each subsequent year of birth, when children improved in height by approximately one-tenth of a standard deviation compared to children born in the previous year $(P<0.001$; Table 2). Therefore, children born in later periods before $E l$ Niño had an improved stature for a given age and sex which reflects the steady improvement in overall nutritional status in this region before the 1997-1998 El Niño. However, those born during the start of El Niño (late July 1997) and shortly after exhibited a lower mean HAZ than what would be expected had El Niño not occurred. Specifically, children born during and after El Niño were only improving by 0.04 standard deviations with each year of birth

Table 1 Sample characteristics

\begin{tabular}{|c|c|c|c|c|c|c|c|}
\hline Year of birth & $\begin{array}{l}\text { Children, } \\
\text { n (\%) }\end{array}$ & $\begin{array}{l}\text { Age in years, } \\
\text { mean (SD) }\end{array}$ & $\begin{array}{l}\text { Male, } \\
\text { n (\%) }\end{array}$ & $\begin{array}{c}\text { Height-for-age } \\
\text { Z-score, mean (SD) }\end{array}$ & $\begin{array}{c}\text { Height-for-age } \\
\text { Z-score }<-2, \text { n (\%) }\end{array}$ & $\begin{array}{l}\text { Socioeconomic status } \\
\text { index, mean (SD) }\end{array}$ & $\begin{array}{c}\text { Mean flood } \\
\text { likelihood, \% (SD) }\end{array}$ \\
\hline 1991 & $126(6.0)$ & $17.9(0.6)$ & $69(54.8)$ & $-1.17(0.81)$ & $18(14.3)$ & $0.36(0.42)$ & $1.4(0.7)$ \\
\hline 1992 & $202(9.6)$ & $16.8(0.5)$ & $114(56.4)$ & $-1.19(0.82)$ & $33(16.3)$ & $0.38(0.40)$ & $1.3(0.6)$ \\
\hline 1993 & 180 (8.6) & $15.8(0.6)$ & $104(52.2)$ & $-1.04(0.98)$ & $27(15.0)$ & $0.40(0.42)$ & $1.2(0.5)$ \\
\hline 1994 & $186(8.9)$ & $14.9(0.6)$ & $104(55.9)$ & $-1.02(0.94)$ & 29 (15.6) & $0.35(0.40)$ & $1.3(0.6)$ \\
\hline 1995 & $189(9.0)$ & $13.9(0.5)$ & $103(54.5)$ & $-0.96(0.94)$ & $31(16.4)$ & $0.34(0.37)$ & $1.2(0.6)$ \\
\hline 1996 & $174(8.3)$ & $12.9(0.5)$ & 85 (48.9) & $-0.69(1.01)$ & $17(9.8)$ & $0.37(0.42)$ & $1.3(0.6)$ \\
\hline 1997 & $195(9.3)$ & $11.8(0.6)$ & $94(48.2)$ & $-0.66(0.95)$ & $15(7.7)$ & $0.38(0.38)$ & $1.3(0.6)$ \\
\hline 1998 & $192(9.2)$ & $10.9(0.6)$ & $93(48.4)$ & $-0.71(1.00)$ & $16(8.3)$ & $0.35(0.40)$ & $1.3(0.6)$ \\
\hline 1999 & $211(10.1)$ & $9.8(0.6)$ & $110(52.1)$ & $-0.67(0.93)$ & $16(7.6)$ & $0.28(0.40)$ & $1.2(0.5)$ \\
\hline 2000 & $210(10.0)$ & $8.8(0.6)$ & $104(49.5)$ & $-0.54(0.98)$ & $13(6.2)$ & $0.34(0.40)$ & $1.3(0.6)$ \\
\hline 2001 & $230(11.0)$ & $7.8(0.5)$ & $128(55.7)$ & $-0.53(0.94)$ & $18(7.8)$ & $0.40(0.40)$ & $1.2(0.4)$ \\
\hline Overall & 2,095 & $12.5(3.2)$ & $1,098(52.4)$ & $-0.81(0.97)$ & $233(11.1)$ & $0.36(0.40)$ & $1.3(0.6)$ \\
\hline
\end{tabular}




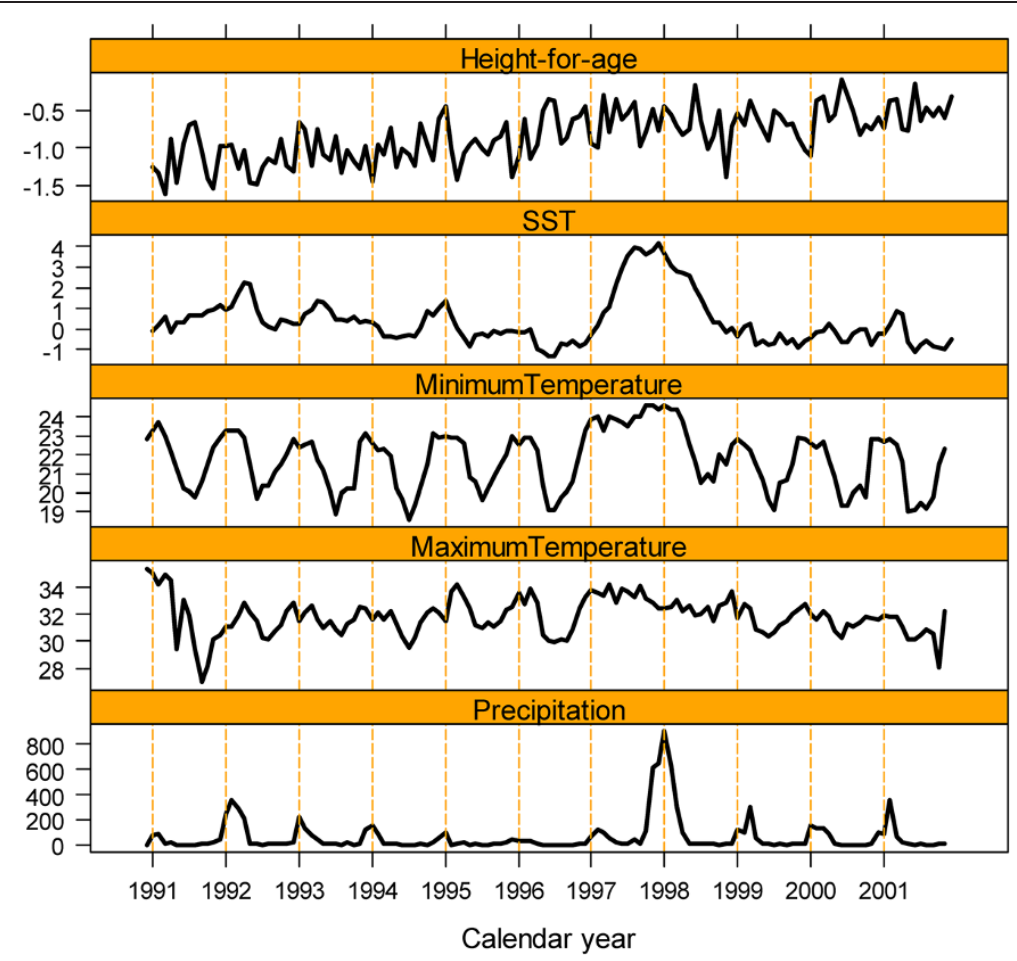

Figure 1 Climate and HAZ in Tumbes. Units for $y$-axis: height-for-age Z-score (HAZ), sea surface temperature (SST, degrees Celsius), minimum and maximum temperatures (degrees Celsius), and precipitation (mm). Precipitation and temperature data for Tumbes for 1991-2001 were obtained from the Peruvian National Weather Service (SENAMHI). SST data were obtained from the International Institute of Climate and Society (IRI).

compared to those born in the previous year, less than half the rate $(44 \%)$ of the pre-El Niño group $(P=0.046)$ (Table 2).

There was a statistically significant interaction between the 1997-1998 El Niño and the likelihood of a child's home being in a location prone to flooding (Table 2), indicating that the direct impact of flooding during $\mathrm{El} \mathrm{Niño}$ was largely responsible for the $E l$ Niño's negative effect on long-term height in young children. Specifically, for every $10 \%$ increase in flooding likelihood of a child's home, the rate of improvement in HAZ with each year of birth declined by 0.13 standard deviations when compared with the rate of improvement in HAZ had El Niño not occurred $(P=0.001)$. Thus, a $50 \%$ increase in flooding likelihood would correspond to two-thirds of a standard deviation decline in the rate of improvement in HAZ with each year of birth. The effect of El Niño in areas with a flooding likelihood of $0 \%$ was negligible $(P=0.14)$.

\section{El Niño affected lean mass but not fat mass}

Fat mass and year of birth had a negative relationship, (Table 3) such that children had $0.89 \mathrm{~kg}$ less fat mass compared to children born in the previous year $(P<0.001)$, and this trend did not change with the occurrence of $E l$ Niño $(P=0.48)$. Similarly, lean mass decreased by $2.1 \mathrm{~kg}$ $(P<0.001)$ with each subsequent year of birth; however, lean mass declined more rapidly, by an additional $1.2 \mathrm{~kg}$ less $(P<0.001)$, for each year of birth for children born after the start of El Niño. In summary, older children in our sample (i.e., children born before $E l$ Niño) have a greater fat mass and lean mass compared to younger children; however, children born after the onset of $E l$ Niño have significantly less lean mass than what would be expected if El Niño had not occurred. There was no relationship between flood likelihood during the 1997$1998 \mathrm{El}$ Niño and either fat mass or lean mass $(P=0.47$ and $P=0.54$, respectively).

\section{Mortality unaffected by El Niño}

The crude birth rate in Tumbes remained unchanged during 1994-2002 $(P=0.77)$ and therefore was unaffected by El Niño. During this same period, both crude infant mortality rates and child mortality rates decreased over time ( $P=0.006$ and $P<0.001$, respectively); however, there were no significant deviations from these trends in 1998 ( $P=0.74$ and $P=0.65$, respectively), the year of the heavy El Niño rainfall.

\section{Discussion}

Two important indicators used in public health to measure the well-being of children are mortality and nutritional status. This study demonstrates that El Niño may have 


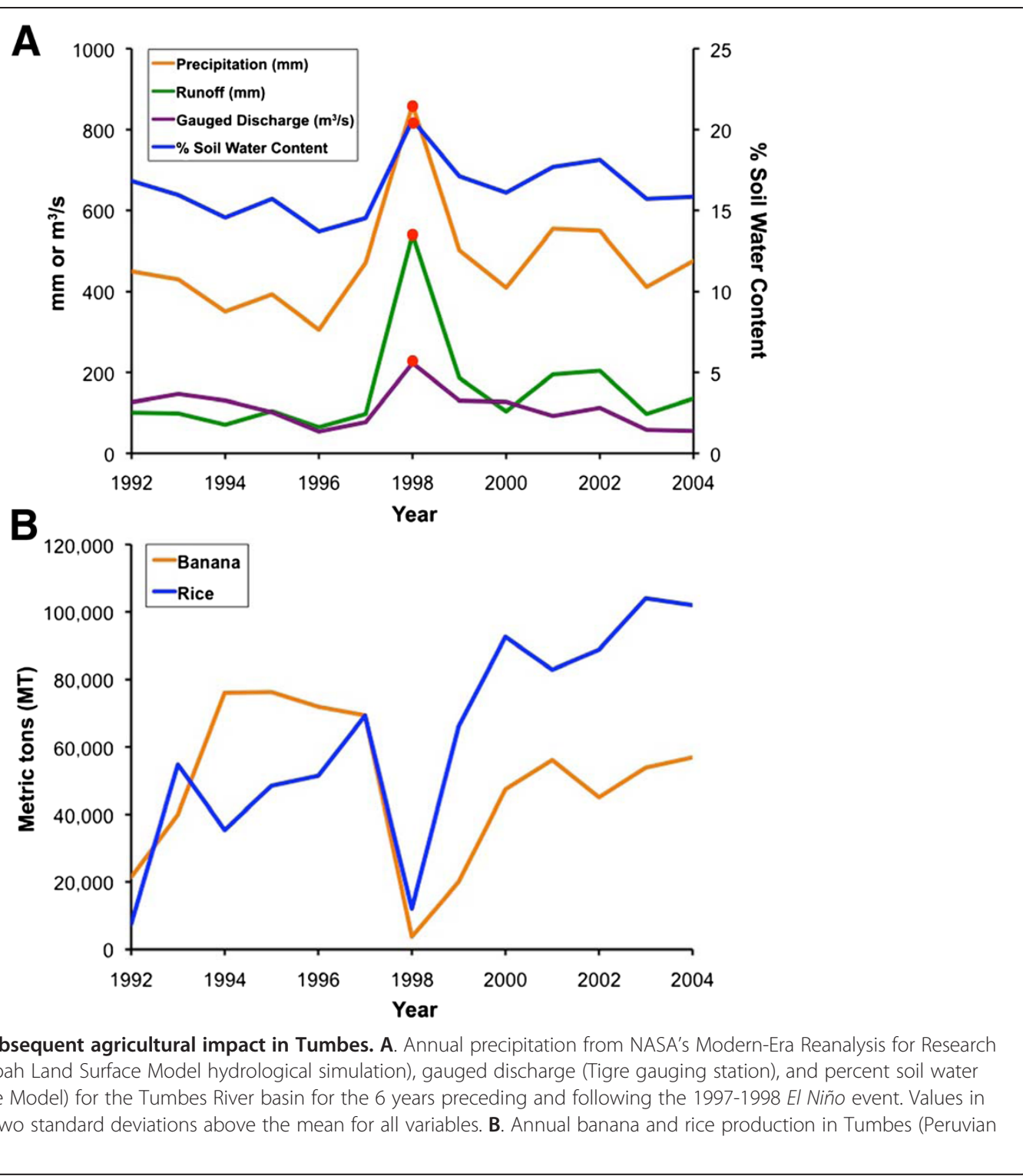

had a marked effect on the long-term nutritional status of children, yet the effect on mortality was negligible. Although the negative effect in height and lean mass was not prevented, if the major effort to intervene by the Peruvian government had not occurred, this disaster might have produced a severe impact on mortality which has been seen in other similar disaster situations such as the 1999 flood in Venezuela [38], the 2000 flood [38] and 20022003 droughts in Mozambique [39], and more recently, the 2009 flood in the Philippines [40] and the 2010 flood in Pakistan [41].

Our original hypothesis anticipated that the 19971998 El Niño would have a negative effect on the age- and sex-adjusted heights of children born during El Niño. These data support this hypothesis and further show that children born both during and after the 1997-1998 El
Niño have a lower HAZ than would be expected if the $E l$ Niño had not occurred. That is, the trend of improvement in HAZ over time in children born in the post-El Niño years (1999-2001) failed to recover to pre-El Niño levels. Thus, the disruption and destruction left by El Niño may not have been resolved during this time, particularly in those regions with the heaviest flooding, having a protracted effect on the nutritional status of children born even 3 years after the initial disaster.

The abating height attainment of children born during and after the 1997-1998 El Niño event may be the result of an increased incidence of infectious illnesses during the period of the El Niño disaster as well as food unavailability. Previous studies conducted in Peru have shown that the incidence of infectious illnesses in children, particularly bouts of diarrhea, spiked during and 


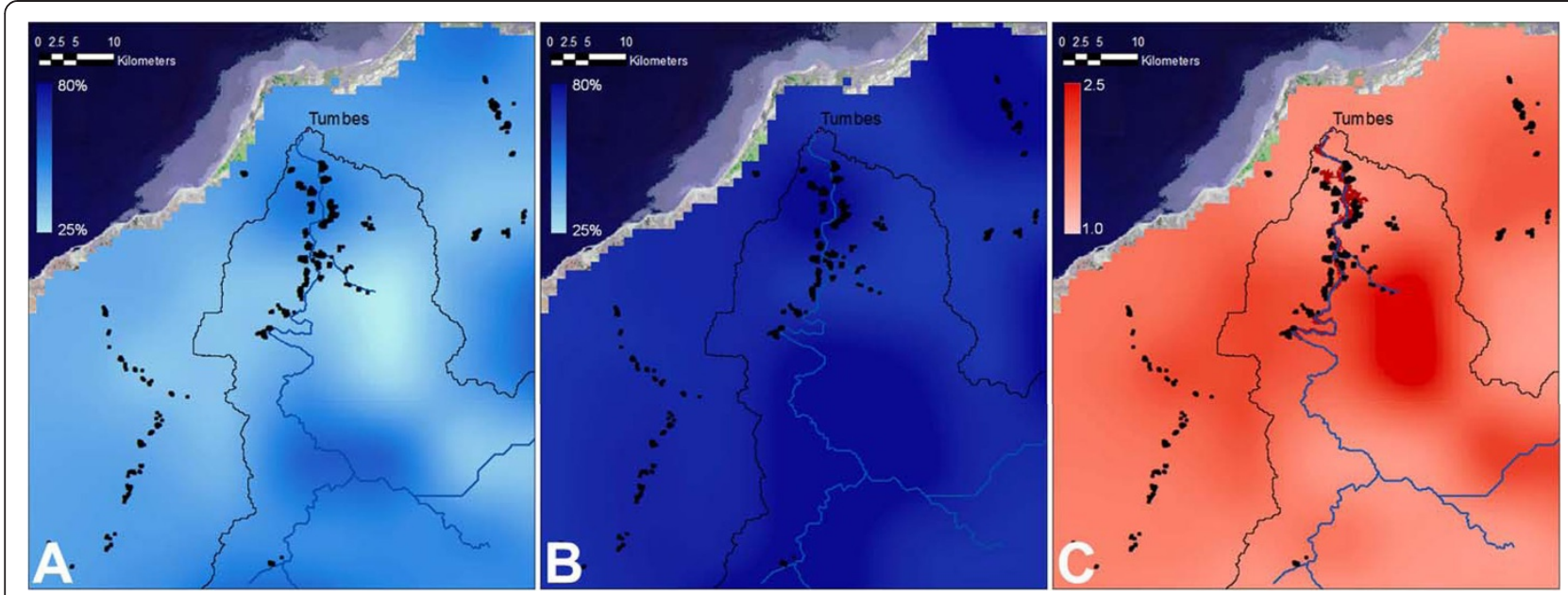

Figure 3 Hydrological impacts. Average degree of soil saturation for January to April in 1995-2004 excluding 1998 (A), and 1998 (B). (C) Ratio of degree of soil saturation in 1998 relative to the 1995-2004 average. All panels also show the locations of households surveyed in this study (black points), the course of Rio Tumbes (blue line), and the boundary of the Rio Tumbes watershed (black line).

after $E l$ Niño likely due to the warmer and wet conditions that accompany El Niño events [15,16]. In addition, El Niño has been linked to epidemics of malaria in northern Peru [5] and dengue in an Ecuadorian region neighboring Tumbes [5,42]. During focus groups conducted in a subsample of Tumbes villages (villages that are also included in our analysis), village members reported an increase in illness and prolonged food shortages, particularly of animal protein foods, during the El Niño period and after [43]. In addition, there was a substantial loss of the chief crops of banana and rice in this region as a result of $E l N i \tilde{n} o$, affecting food availability and prices as well as the economic livelihood of these communities, which largely rely on the export of these crops. In conclusion, it is possible that children born during the disaster as well as during its aftermath may have been more likely to have an infectious illness and less likely to have a diet adequate for optimal growth, which may explain the negative association of $E l$ Niño and height attainment in these children found in our results.
El Niño had an impact on lean mass but not fat mass regardless of the amount of flood exposure. It is not surprising that El Niño may have adversely affected only lean mass given that later body composition is strongly influenced by the nutritional environment experienced in early life, during both the prenatal and postnatal periods [44]. Previous studies from diverse populations have shown relatively consistent findings, in that birth weight is positively associated with later lean mass but not fat mass, indicating that reduction in fetal growth diminishes later lean mass [44]. Findings for infant weight gain differ between industrialized and developing countries; in the latter, based on studies from Brazil, Guatemala, and India, infant weight gain is again positively associated with later lean mass but not fat mass, indicating that poor infant growth would constrain later lean mass [44]. Lean mass is an important predictor of physical work capacity in later life $[45,46]$, which may have important implications for productivity particularly in primarily agricultural and fishing communities such a

Table 2 Change in Height-for-age Z-score (HAZ) after onset of 1997-1998 El Niño

\begin{tabular}{|c|c|c|c|c|}
\hline \multirow[t]{2}{*}{ Variable } & \multicolumn{2}{|c|}{ With interaction term } & \multicolumn{2}{|c|}{ Without interaction term } \\
\hline & $\beta(95 \% \mathrm{Cl})$ & $P$ value & $\beta(95 \% \mathrm{Cl})$ & $P$ value \\
\hline Intercept & $-1.443(-1.579,-1.306)$ & $<0.001$ & $-1.445(-1.584,-1.305)$ & $<0.001$ \\
\hline \multicolumn{5}{|l|}{ Year of birth } \\
\hline HAZ slope before El Niño & $0.093(0.070,0.117)$ & $<0.001$ & $0.095(0.072,0.118)$ & $<0.001$ \\
\hline Change in HAZ slope after El Niño & $-0.052(-0.104,-0.001)$ & 0.05 & $-0.039(-0.091,0.013)$ & 0.14 \\
\hline Female (male is reference) & $-0.001(-0.078,0.076)$ & 0.99 & $-0.002(-0.079,0.075)$ & 0.96 \\
\hline Socioeconomic status index & $0.449(0.341,0.557)$ & $<0.001$ & $0.446(0.338,0.554)$ & $<0.001$ \\
\hline Flood likelihood & $-0.462(-1.757,0.832)$ & 0.48 & $-0.020(-1.341,1.301)$ & 0.98 \\
\hline Interaction flood likelihood × El Niño & - & & $-1.321(-2.130,-0.512)$ & 0.001 \\
\hline
\end{tabular}


Table 3 Change in fat mass and lean mass after onset of 1997-1998 El Niño

\begin{tabular}{|c|c|c|c|c|}
\hline \multirow[t]{2}{*}{ Variable } & \multicolumn{2}{|c|}{ With interaction term } & \multicolumn{2}{|c|}{ Without interaction term } \\
\hline & $B(95 \% \mathrm{Cl})$ & $P$ value & B $(95 \% \mathrm{Cl})$ & $P$ value \\
\hline \multicolumn{5}{|l|}{ Fat mass (kilograms) } \\
\hline Intercept & $11.94(10.62,13.25)$ & $<0.001$ & $11.91(10.59,13.23)$ & $<0.001$ \\
\hline \multicolumn{5}{|l|}{ Year of birth } \\
\hline HAZ slope before the 1997-1998 El Niño & $-0.89(-1.12,-0.65)$ & $<0.001$ & $-0.88(-1.12,-0.64)$ & $<0.001$ \\
\hline Change in HAZ slope after El Niño & $0.19(-0.34,0.72)$ & 0.48 & $0.21(-0.32,0.75)$ & 0.44 \\
\hline Female (male is reference) & $4.03(3.22,4.83)$ & $<0.001$ & $4.02(3.22,4.83)$ & $<0.001$ \\
\hline Socioeconomic status index & $2.49(1.36,3.61)$ & $<0.001$ & $2.48(1.35,3.60)$ & $<0.001$ \\
\hline Flood likelihood & $3.02(-6.74,12.77)$ & 0.54 & $4.03(-6.26,14.32)$ & 0.44 \\
\hline Interaction flood likelihood?×?El Niño & - & & $-4.00(-14.91,6.90)$ & 0.47 \\
\hline \multicolumn{5}{|l|}{ Lean mass (kilograms) } \\
\hline Intercept & $48.85(47.71,49.99)$ & $<0.001$ & $48.84(47.70,49.98)$ & $<0.001$ \\
\hline \multicolumn{5}{|l|}{ Year of birth } \\
\hline HAZ slope before El Niño & $-2.05(-2.24,-1.16)$ & $<0.001$ & $-2.04(-2.23,-1.85)$ & $<0.001$ \\
\hline Change in HAZ slope after El Niño & $-1.16(-1.58,-0.74)$ & $<0.001$ & $-1.14(-1.56,-0.72)$ & $<0.001$ \\
\hline Female (male is reference) & $-5.39(-6.03,-4.76)$ & $<0.001$ & $-5.40(-6.03,-4.77)$ & $<0.001$ \\
\hline Socioeconomic status index & $1.75(0.82,2.68)$ & $<0.001$ & $1.74(0.81,2.67)$ & $<0.001$ \\
\hline Flood likelihood & $-3.86(-14.62,6.89)$ & 0.48 & $-3.72(-14.54,7.11)$ & 0.50 \\
\hline Interaction flood likelihood?×?El Niño & - & & $-2.78(-11.66,6.11)$ & 0.54 \\
\hline
\end{tabular}

Tumbes. Similar to height, El Niño's effect on decreasing lean mass may have been the result of the unavailability of nutrient- or energy-dense foods to those children born during the disaster and the aftermath. More research is needed to further understand the mechanisms by which the El Niño disaster affects growth in young children.

Just as rings act as indicators of natural disasters experienced by a tree throughout its life [47], exposure to severe adverse weather events in utero or early life can leave a long-lasting mark on growth and development in young children. In low- and middle-income countries, a child who undergoes inadequate growth early in life is unlikely to achieve complete catch-up growth later on [19]. Early shortfalls generally persist into adult life. As noted, stunting is a marker for decreased mental and physical capacity [21-23,27]. Early disruptions to lean mass appear to affect its constituent components unequally, protecting the brain at the expense of other organs and tissues such as the kidneys, liver, pancreas, and muscle mass $[48,49]$. These effects also vary as to whether they occur in fetal life or infancy. In later life, such constraints on early growth are predicted to reduce the capacity for homeostasis, and increase the risk of chronic degenerative diseases, as shown extensively elsewhere [26].

Our study has some potential limitations. First, due to the nature of the cross-sectional study design, nutritional measurements (height, weight, and body composition) were taken at only one time point for each child, and therefore, inferences cannot be made regarding the change in height across time at the individual level. In addition, we do not have earlier information such as birth weight or any illness history prior to or during the 1997-1998 El Niño episode. Despite this, our data include nutritional measurements for children across several birth cohorts and therefore allow for comparisons of the mean average change in height, lean mass, and fat mass between birth year cohorts. Second, we define exposure to El Niño in early life as having a birth year that coincides with the onset (or after) of El Niño. It is possible that the effects on height attainment and lean mass may be due to other events that may have occurred during the same period as the onset and aftermath of the El Niño disaster; however, in focus groups conducted in a subsample of villages in Tumbes, community members did not cite other events occurring during the same period as El Niño that had such a destructive impact on their lives [43]. Third, we may have been underpowered to detect a possible effect on lean mass in households with higher flood likelihood. Fourth, our study may be less representative of older children in our cohort, as many of them were either hard to reach because they were working and difficult to find or were married and had moved to another household or another village. Lastly, the variables used to generate the SES index were based on self-report. As with any self-reported information, these variables are subject to reporting bias; however, if bias were present in our data, the results would 
be biased towards the null making our estimates conservative and not changing our final conclusions.

Despite these limitations, our study has several strengths. First, both villages and children within each birth cohort were randomly selected. Therefore, we are confident that our sample is representative of the study population. Second, we used standardized and consistent methods to measure height, weight, and body composition across all children, and therefore the measurements are reliable and can also be compared with other populations. Third, only children who had lived in Tumbes since 1 year of age were eligible for enrollment eliminating a possible risk of bias from migration. Finally, as shown in our analyses, our results are not likely to be affected by migration or a mortality difference.

\section{Conclusions}

If adverse weather events affect a significant portion of young children of a country, then they have the potential to adversely affect the future of a community as a whole. Some investigators hypothesize that global warming will translate into more frequent $\mathrm{El} \mathrm{Niño} \mathrm{episodes} \mathrm{[50,51]}$ heightening the urgency of the global health issues consequential to weather events accompanying El Niño. Because children and those in lower SES levels are most vulnerable to the health and economic impacts of disasters [52], including those induced by $\mathrm{El} \mathrm{Niño}$, it is imperative that we continue to explore the extent to which they are affected to design prevention strategies and target aid and relief during future $E l$ Niño episodes.

\section{Additional file}

Additional file 1: Supplementary information. This file contains figures and tables on study hypothesis, Department of Tumbes, SST, predicted $H A Z$, and household socioeconomic variables.

\section{Abbreviations}

HAZ: height-for-age Z-score; SES: socioeconomic status.

\section{Competing interests}

The authors declare that they have no competing interests.

\section{Authors' contributions}

HED, RHG, JCW, and WC made contributions to the design of the study. HED coordinated the fieldwork, and HED and WC wrote the first draft. RHG, JCW, WP, and BZ provided important revisions. HED, WP, BZ, and WC conducted data analysis. GG and MA provided essential field support. All authors read and approved the final manuscript.

\section{Acknowledgements}

We thank the Center for Global Health of Universidad Peruana Cayetano Heredia in Tumbes, Peru, for contributing local census information as well as for their invaluable insight on effectively conducting a research study in Tumbes communities. This study was supported by the Fogarty International Center Training Grant (Grant R24 TW007988). William Checkley was supported by a Clinician Scientist Award from the Johns Hopkins University, a K99/R00 Pathway to Independence Award (K99HL096955) from the National Heart, Lung and Blood Institute, National Institutes of Health. Heather Danysh was supported by a pre-doctoral NIH T35 Training Grant
(T35Al065385). Funding agencies did not have a role in the design, analysis, or interpretation of data.

\section{Author details}

${ }^{1}$ Program in Global Disease Epidemiology and Control, Department of International Health, Bloomberg School of Public Health, Johns Hopkins University, Baltimore 21218, USA. "'Biomedical Research Unit, Asociación Benéfica PRISMA, Lima 32, Perú. ${ }^{3}$ Institute of Child Health, University College London, London WC1N 1EH, UK. ${ }^{4}$ Duke Global Health Institute and Nicholas School of Environment, Duke University, Durham, NC 27708, USA.

${ }^{5}$ Department of Earth and Planetary Sciences, Johns Hopkins University, Baltimore 21218, USA. ${ }^{6}$ Departamento de Microbiología, Facultad de Ciencias y Filosofía, Universidad Peruana Cayetano Heredia, Lima 430, Perú. ${ }^{7}$ Division of Pulmonary and Critical Care, Johns Hopkins University, 1830 Monument St, Fifth Floor, Baltimore, MD 21205, USA.

Received: 31 December 2013 Accepted: 23 April 2014

Published online: 25 November 2014

\section{References}

1. Glantz MH: Currents of Change: Impacts of El Niño and La Niña on Climate and Society. 2nd edition. Cambridge: Cambridge University Press; 2001.

2. Bouma MJ, Kovats RS, Goubet SA, Cox JS, Haines A: Global assessment of El Niño's disaster burden. Lancet 1997, 350:1435-1438.

3. Bouma MJ, Dye C: Cycles of malaria associated with El Niño in Venezuela. JAMA 1997, 278:1772-1774.

4. Bouma MJ, van der Kaay HJ: The El Niño Southern Oscillation and the historic malaria epidemics on the Indian subcontinent and Sri Lanka: an early warning system for future epidemics? Trop Med Int Health 1996, 1:86-96.

5. Gagnon AS, Smoyer-Tomic KE, Bush AB: The El Niño southern oscillation and malaria epidemics in South America. Int J Biometeorol 2002, 46:81-89.

6. Grillet ME, El Souki M, Laguna F, Leon JR: The periodicity of Plasmodium vivax and Plasmodium falciparum in Venezuela. Acta Trop 2014, 129:52-60.

7. Cazelles B, Chavez M, McMichael AJ, Hales S: Nonstationary influence of El Niño on the synchronous dengue epidemics in Thailand. PLOS Med 2005, 2:e106.

8. Colon-Gonzalez FJ, Lake IR, Bentham G: Climate variability and dengue fever in warm and humid Mexico. Am J Trop Med Hyg 2011, 84:757-763.

9. Gagnon AS, Bush AB, Smoyer-Tomic KE: Dengue epidemics and the El Niño Southern Oscillation. Clim Res 2001, 19:35-43.

10. Hales $S$, Weinstein P, Souares $Y$, Woodward A: El Niño and the dynamics of vectorborne disease transmission. Environ Health Perspect 1999, 107:99-102

11. Colwell RR: Global climate and infectious disease: the cholera paradigm Science 1996, 274:2025-2031.

12. Gil Al, Louis VR, Rivera IN, Lipp E, Huq A, Lanata CF, Taylor DN, RussekCohen E, Choopun N, Sack RB, Colwell RR: Occurrence and distribution of Vibrio cholerae in the coastal environment of Peru. Environ Microbiol 2004, 6:699-706.

13. Pascual M, Rodo X, Ellner SP, Colwell R, Bouma MJ: Cholera dynamics and El Niño-Southern Oscillation. Science 2000, 289:1766-1769.

14. Speelmon EC, Checkley W, Gilman RH, Patz J, Calderon M, Manga S: Cholera incidence and El Niño-related higher ambient temperature. JAMA 2000, 283:3072-3074.

15. Bennett A, Epstein LD, Gilman RH, Cama V, Bern C, Cabrera L, Lescano AG, Patz J, Carcamo C, Sterling CR, Checkley W: Effects of the 1997-1998 El Niño episode on community rates of diarrhea. Am J Public Health 2012, 102:e63-69.

16. Checkley W, Epstein LD, Gilman RH, Figueroa D, Cama RI, Patz JA, Black RE: Effect of El Niño and ambient temperature on hospital admissions for diarrhoeal diseases in Peruvian children. Lancet 2000, 355:442-450.

17. Allen LH: Nutritional influences on linear growth: a general review. Eur J Clin Nutr 1994, 48(Suppl):S75-89.

18. Black RE, Allen LH, Bhutta ZA, Caulfield LE, de Onis M, Ezzati M, Mathers $C$, Rivera J: Maternal and child undernutrition: global and regional exposures and health consequences. Lancet 2008, 371:243-260.

19. Checkley W, Buckley G, Gilman RH, Assis AM, Guerrant RL, Morris SS, Molbak K, Valentiner-Branth P, Lanata CF, Black RE: Multi-country analysis of the effects of diarrhoea on childhood stunting. Int J Epidemiol 2008, 37:816-830. 
20. Coly AN, Milet J, Diallo A, Ndiaye T, Benefice E, Simondon F, Wade S, Simondon KB: Preschool stunting, adolescent migration, catch-up growth, and adult height in young Senegalese men and women of rural origin. J Nutr 2006, 136:2412-2420.

21. Olney DK, Kariger PK, Stoltzfus RJ, Khalfan SS, Ali NS, Tielsch JM, Sazawal S, Black R, Allen LH, Pollitt E: Development of nutritionally at-risk young children is predicted by malaria, anemia, and stunting in Pemba, Zanzibar. J Nutr 2009, 139:763-772.

22. Kariger PK, Stoltzfus RJ, Olney D, Sazawal S, Black R, Tielsch JM, Frongillo EA, Khalfan SS, Pollitt E: Iron deficiency and physical growth predict attainment of walking but not crawling in poorly nourished Zanzibari infants. J Nutr 2005, 135:814-819.

23. Berkman DS, Lescano AG, Gilman RH, Lopez SL, Black MM: Effects of stunting, diarrheal disease, and parasitic infection during infancy on cognition in late childhood: a follow-up study. Lancet 2002, 359:564-571.

24. Alderman $\mathrm{H}$, Hoddinott J, Kinsey B: Long term consequences of early childhood malnutrition. Oxford Economic Papers 2006, 58:450-474.

25. Grantham-McGregor S, Cheung YB, Cueto S, Glewwe P, Richter L, Strupp B: Developmental potential in the first 5 years for children in developing countries. Lancet 2007, 369:60-70.

26. Victora CG, Adair L, Fall C, Hallal PC, Martorell R, Richter L, Sachdev HS: Maternal and child undernutrition: consequences for adult health and human capital. Lancet 2008, 371:340-357.

27. Velasco AZ, Sueiro JC: El fenómeno "El Niño" y el poder ejecutivo en el Perú. In SEPIA VIII: Impacto de "EI Niño": Investigaciones Arqueológicas en la Costa Norte. Seminario Permanente de Investigación Agraria (SEPIA): Chiclayo, Perú; 1999.

28. United Nations Office for the Coordination of Humanitarian Affairs: Peru El Niño Floods OCHA Situation Report No. 12 (OCHAGVA - 98/0210). [http://reliefweb.int/node/37383]

29. de Onis M, Onyango AW, Van den Broeck J, Chumlea WC, Martorell R: Measurement and standardization protocols for anthropometry used in the construction of a new international growth reference. Food Nutr Bull 2004, 25:S27-36.

30. Davies PS, Wells JC: Calculation of total body water in infancy. Eur J Clin Nutr 1994 48:490-495.

31. Wells JC, Fewtrell MS: Measuring body composition. Arch Dis Child 2006, 91:612-617.

32. Wells JC, Williams JE, Chomtho S, Darch T, Grijalva-Eternod C, Kennedy K, Haroun D, Wilson C, Cole TJ, Fewtrell MS: Pediatric reference data for lean tissue properties: density and hydration from age 5 to $20 \mathrm{y}$. Am J Clin Nutr 2010, 91:610-618.

33. Chen F, Mitchell K, Schaake J, Xue YK, Pan HL, Koren V, Duan QY, Ek M, Betts A: Modeling of land surface evaporation by four schemes and comparison with FIFE observations. J Geophys Res Atmos 1996, 101:7251-7268.

34. Ek MB, Mitchell KE, Rogers E, Grunmann P, Koren V, Gayno G, Tarpley JD: Implementation of Noah land surface model advances in the National Centers for Environmental Prediction operational mesoscale Eta model. J Geophys Res Atmos 2003, 108:8851.

35. Rienecker MM, Suarez MJ, Gelaro R, Todling R, Bacmeister J, Liu E, Bosilovich MG, Schubert SD, Takacs L, Kim GK, Bloom S, Chen J, Collins D, Conaty A, da Silva A, Gu W, Joiner J, Koster RD, Lucchesi R, Molod A, Owens T, Pawson S, Pegion P, Redder CR, Reichle R, Robertson FR, Ruddick AG, Sienkiewicz M, Woollen J: MERRA: NASA's Modern-Era Retrospective Analysis for Research and Applications. Journal of Climate 2011, 24:3624-3648.

36. Filmer D, Pritchett LH: Estimating wealth effects without expenditure data-or tears: an application to educational enrollments in states of India. Demography 2001, 38:115-132.

37. Vyas S, Kumaranayake L: Constructing socio-economic status indices: how to use principal components analysis. Health Policy Plan 2006, 21:459-468.

38. Few R, Franziska M: Flood Hazards \& Health: Responding to Present and Future Risks. London: Earthscan; 2007.

39. Renzaho AM: Mortality rates, prevalence of malnutrition, and prevalence of lost pregnancies among the drought-ravaged population of Tete Province, Mozambique. Prehosp Disaster Med 2007, 22:26-34.

40. Amilasan AS, Ujiie M, Suzuki M, Salva E, Belo MC, Koizumi N, Yoshimatsu K, Schmidt WP, Marte S, Dimaano EM, Villarama JB, Ariyoshi K: Outbreak of leptospirosis after flood, the Philippines, 2009. Emerg Infect Dis 2012, 18:91-94.
41. Warraich H, Zaidi AK, Patel K: Floods in Pakistan: a public health crisis. Bull World Health Organ 2011, 89:236-237.

42. Stewart-Ibarra AM, Lowe R: Climate and non-climate drivers of dengue epidemics in southern coastal Ecuador. Am J Trop Med Hyg 2013, 88:971-981.

43. Bayer AM, Danysh HE, Garvich M, Gonzalvez G, Checkley W, Alvarez M, Gilman RH: An unforgettable event: a qualitative study of the 1997-98 El Nino in northern Peru. Disasters 2014, 38:351-374.

44. Wells JC, Chomtho S, Fewtrell MS: Programming of body composition by early growth and nutrition. Proc Nutr Soc 2007, 66:423-434.

45. Haas JD, Martinez EJ, Murdoch S, Conlisk E, Rivera JA, Martorell R: Nutritional supplementation during the preschool years and physical work capacity in adolescent and young adult Guatemalans. J Nutr 1995, 125:1078S-1089S.

46. Martorell R: Results and implications of the INCAP follow-up study. J Nutr 1995, 125:1127S-1138S.

47. Miller DL, Mora Cl, Grissino-Mayer HD, Mock CJ, Uhle ME, Sharp Z: Tree-ring isotope records of tropical cyclone activity. Proc Natl Acad Sci USA 2006, 103:14294-14297.

48. Latini G, De Mitri B, Del Vecchio A, Chitano G, De Felice C, Zetterstrom R Foetal growth of kidneys, liver and spleen in intrauterine growth restriction: "programming" causing "metabolic syndrome" in adult age. Acta Paediatr 2004, 93:1635-1639.

49. Yajnik CS, Fall CH, Coyaji KJ, Hirve SS, Rao S, Barker DJ, Joglekar C, Kellingray S: Neonatal anthropometry: the thin-fat Indian baby. The Pune Maternal Nutrition Study. Int J Obes Relat Metab Disord 2003, 27:173-180.

50. Fedorov AV, Philander SG: Is El Niño changing? Science 2000 288:1997-2002

51. Timmermann A, Oberhuber J, Bacher A, Esch M, Latif M, Roeckner E: Increased El Niño frequency in a climate model forced by future greenhouse warming. Nature 1999, 398:694-697.

52. Brouwer $R$, Akter $S$, Brander $L$, Haque E: Socioeconomic vulnerability and adaptation to environmental risk: a case study of climate change and flooding in Bangladesh. Risk Anal 2007, 27:313-326.

doi:10.1186/s40665-014-0007-z

Cite this article as: Danysh et al:: El Niño adversely affected childhood stature and lean mass in northern Peru. Climate Change Responses 2014 1:7.

\section{Submit your next manuscript to BioMed Central and take full advantage of:}

- Convenient online submission

- Thorough peer review

- No space constraints or color figure charges

- Immediate publication on acceptance

- Inclusion in PubMed, CAS, Scopus and Google Scholar

- Research which is freely available for redistribution 